\title{
The Potential Use of Wild Swamp Vegetables Through an Ethnobothanical Survey
}

\section{SASI GENDRO SARI ${ }^{1}{ }^{*}$, FIDHI WIDYA SARI ${ }^{1}$, , ${ }_{\text {AND }}$ ENY DWI PUDJAWATI ${ }^{2}$}

${ }^{1}$ Department of Biology, Faculty of Mathematics and Natural Sciences, Lambung MangkuratUniversity. Jl. A. Yani km. 35,8 Banjarbaru - South Kalimantan, Indonesia. Tel./Fax. +62-5114773112;

${ }^{2}$ Faculty of Forestry, Lambung Mangkurat University, Jl. A. Yani km. 35,8 Banjarbaru - South Kalimantan, Indonesia

\begin{abstract}
Swamp areas provide basic needs for local communities living in wetland areas, especially in the Banjar regency, South Kalimantan. Indigenous people of Banjar regency, called Banjarese or the Banjar people, are consuming wild swamp vegetables and processing them into traditional food combined with rice. The potential use of swamp plants for vegetables by Banjarese was investigated through an ethnobotanical study. The vegetables were obtained from three selected lowland swamps located in three villages of Banjar regency namely Panjambuan, Sungai Batang and Sungai Tuan Ilir. Wild swamp vegetables were identified using a semi structured questionnaire technique and 72 respondents were selected by a purposive sampling based on their interaction with swamps. The respondents were classified into gender, and four groups based on their ages to determine knowledge level in utilizing wild swamp vegetables. After that, their level knowledge was tested based on gender and ages using Kruskal Wallis test. Mann Whitney U-test was applied to distinguish the difference of knowledge level from ages and sex. The findings observed were six wild swamp vegetables used by Banjarese such as water spinach Ipomoea aquatica, genjer Limnocharis flava, hairy water lily Nymphaea pubescens, water mimosa Neptunia oleracea, taro Colocasia esculenta and swamp fern Stenochlaena palustris. All parts of the plants were used except for the roots. Leaves were preferably cooked with $44.5 \%$ in comparison to other parts of plants like stem, flower, tendril and corm. Water spinach was frequently consumed by Banjarese compared to other plants. The knowledge level of local people was 67.84 categorized as a middle level and an elderly more than 60 years old had the highest knowledge level in using swamp plants compared to other groups. Moreover, women had better knowledge rather than men to utilize wild swamp plants for food.
\end{abstract}

Keywords: Banjarese, ethnobotany, knowledge, wild swamp vegetables

\section{INTRODUCTION}

Local people live in or adjacent to wetlands such as swamps because this unique habitat provides people with a variety of ecosystem services such as natural resources, maintaining hydrological system and local livelihoods. Most local communities depend heavily on swamps to fulfil their basic needs including water, food, medicine and shelter (Page et al., 2011; Wetland International, 2010). Stuip et al. (2002) stated that communities often

Correspondence Author: Sasi Gendro Sari. Department of Biology, Faculty of Mathematics and Natural Sciences, Lambung Mangkurat University. Jl. A. Yani km. 35.8 Banjarbaru - South Kalimantan, Indonesia. Email:sgsari@ulm.ac.id achieve their basics of life directly from swamps. They usually use wild swamp plants for food, medicinal purposes, household constructions and even growing rice and undertaking other agricultural activities in the swamps. Therefore, swamps play an important role in contributing to household food security and provide local people with an income.

Banjarese is a local community which is estimated more than $70 \%$ of the whole population are lived in Kalimantan (Raihani, 2018). The amount of this tribe is more than 2.6 million people who $74.34 \%$ of inhabitants are living in South Kalimantan in the year of 2010 (Pitoyo and Triwahyudi, 2017). Banjarese have been using wild swamp 
vegetables for many years and the use of these plants have rarely researched. The traditional indigenous vegetables are a part of pluralism in using wild food plants (Susanti, 2005). Nowadays, local vegetables are more famously known for their nutritional values to secure million of people from malnutrition (Lyatuu \& Lebotse, 2010) and they contain higher fibers, phenolic contents and antioxidant properties than cultivated plants (Leonti et al., 2006; Chai et al., 2012). Additionally, these vegetables can protect human bodies from several degenerative and chronic diseases (Romojaro et al., 2013; Maritim et al., 2003; Chai et al., 2012).

The way local communities consume wild swamp plants slowly becomes an integral section of traditional botanical knowledge and influence the practise of living. However, traditional botanical knowledge progressively disappeared in rural societies (Sansanelli et al., 2017; Arowosegbe et al., 2018). The documentation of wild swamp vegetables consumed by the Banjar is limited and needs to be documented. Factors responsible according to Shei (2008) are civilization and inadequate information on nutritional and medicinal benefits among societies.

Ethnobotanical studies reveal the interaction between people and plants. The study focuses on the utilization of plants for food, medicine, household, shelter, ritual culture, etc, and applies to develop human live. Furthermore, ethnobotany also conducts how indigenous society affect social culture and natural resources. Also, it is necessary to record and assess the level knowledge of indigenous people in order to establish their culture, which plays an important role in safeguarding this knowledge and conserving the local plants (Suryadarma, 2008; Purwanto, 1999). Martin et al. (2010) stated that local knowledge is a fascinating dynamic and sustainability among societies.

Cotton (1996) stated that interest in ethnobotany has increased dramatically to find the potential uses of plants by indigenous communities. Many explorations in documentating the value of local plants have been done intensively by researchers to disclose traditional utilization of plants by tribal and rural societies from other parts of the world. Searching medicinal plants and edible plants for food are making contribution to document plant diversity and therefore the conservation of vulnerable ecosystems. The documented data according to Teklehaymanot (2009) could be useful for future studies. Studies of the potential uses of wild plants can lead to new sources of drugs and food security. Much of utilizing local plants have survived among indigenous people; however, the trend of knowledge loss has been increasing tremendously along with the people and less handed down from generation to generation (Arowosegbe et al., 2018; Sansanelli et al., 2017; Teklehaymanot, 2009). Traditional and indigenous communities are normaly recording their knowledge and experiences in oral traditions and oral histories because they are lacking a writing system. Some tribes still practice regularly and depend largely on their ancient knowledge (Ray, 2015). Hence, the preserving of ethnobotanical knowledge as a section of social-cultural practices for many centuries from societies to environments plays crucial roles for biodiversity conversation (Martin et al., 2010; Xu et al., 2005; Cotton, 1996).

The potency of wild plants should be distinguished (Arowosegbe et al., 2018; Teklehaymanot, 2009; Martin et al., 2010) because they have a great benefit for human welfare, particularly in the wetland areas such 
as lowland swamps (Stuip et al., 2002). It is believed that many potencies of wild swamp plants are still undiscovered and need ethnobiological studies to find the advantages for human survival before those plants disappears due to habitat fragmentations such as growing rice and other aquacultural activities in wetlands (Wetland International, 2010; Stuip et al. 2002).

In general, lowland swamps are not viewed as valuable resources (Stuip et al., 2002) and regarded as ecosystem with less value or a lower price for development. According to Millennium Ecosystem Assessment (2005) more than a half of the wetlands globally have been degraded due to factors driving change such as fragmentation habitat, land cover change, water extraction, infrastructure development, pollution, overexploitation and the introducing of invasive spesies. Pollution, such as waste disposal, cause an extremely negative impact on swamp degradation. Waste disposal can affect fish production, quality of water, sensitive local plants, etc. Domestic pollution and other waste can cause diseases such as diarrhoea, dysentery, malaria, schistosomiasis, etc (WI, 2010). Swamp dependent local societies are highly vulnerable to water related diseases due to a lack of access to clean water, good sanitation and the effect on poor food quality.

According to previous findings, solely one study of local lowland swamp vegetables was performed in South Kalimantan particularly at Martapura traditional market. The results stated that the availability of local lowland swamp vegetables fluctuated depended on the season and people who were carrying them to the market. Surprisingly, the benefit of local swamp vegetables for people's health were not known by local respondents from some tribes (the Banjar, Java tribe, and Dayak tribe)
(Susanti, 2005). Therefore, investigation and documentation of the level of knowledge from specific tribe, such as the Banjar, on the use of wild edible plants need to be considered and could fill the knowledge gap of indigenous tribes on the utilizing wild lowland swamp vegetables.

The potential use of swamp plants for food needs to take into account specifically with regard to gender and age of the informants. Moreover, recording the level knowledge on using wild swamp vegetables consumed by Banjarese in three villages located near selected swamps, which are part of Banjar regency, South Kalimantan province should be identified.

\section{MATERIAL AND METHODS}

The research was conducted in three selected lowland swamps at the villages Pejambuan, Sungai Tuan Ilir and Sungai Batang, which are part of Banjar regency in South Kalimantan province, Indonesia. The survey was done between March and July, 2017. These villages are in the tropic region with a total area of about $27,964.90$ hectares and at least 20,000 hectares covered by swamps (Figure 1). The total population of these three villages was 4,610 people, consisting of 2,370 men and 2,240 women (Local Government of Banjar Regency, 2006). The majority of occupation is a rice farmer while the dominating tribe is Banjarese.

Seventy-two respondents were selected purposively based on their interaction with the swamps and domicile in the selected villages for a period of 15 years. Each village had 24 informants and, age class was taken into account. The criteria of age were done according to Zent (2009) on productive age. The first class is ranging in age from 15 to 29 


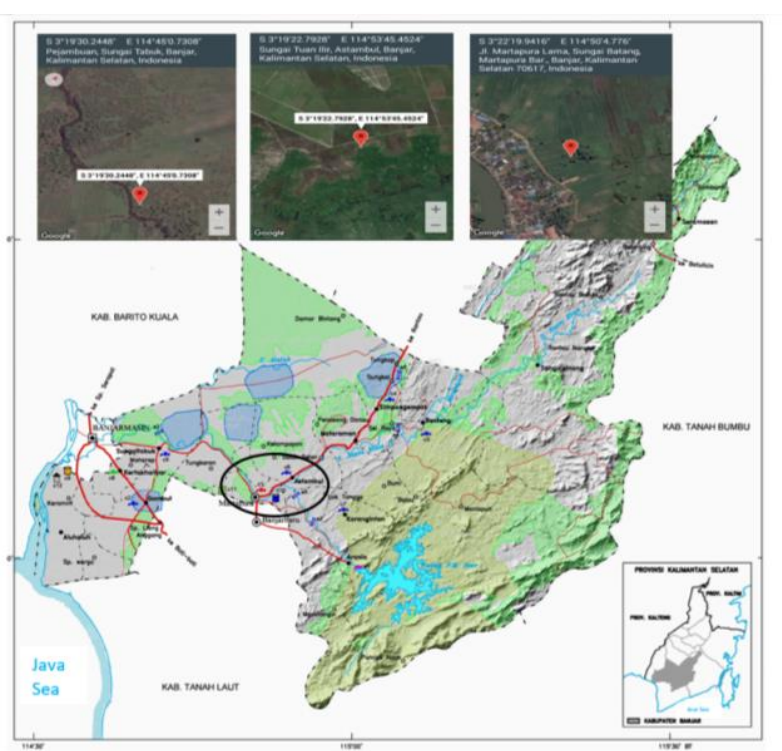

Figure 1. Map of Banjar regency with study sites

years and the second classis between 30 and 44 years of age. The third class is from 45 to 59 years old and $\geq 60$ years of age is the last class.

The interviews were carried out with semistructured questionnaire (Martin, 2010) and allowed two-way conversations between interviewer and informants. Informants were asked about what kind of wild swamp vegetables they consumed, plant parts harvested and processing technique of traditional food. Plant specimens of resulting interviews were collected.

Percentage of plant parts used was counted and the relative frequency of citation index (RFC) was defined based on Tardio\& Pardode-Santaya. (2008). The value ranges from 0 , when no one refers to used plants, to 1 , when all informants mention the utilization of plants.

$$
R F C=\frac{N p}{N}
$$

where

$\mathrm{Np}=$ the number of respondents who used wild swamp vegetables

$\mathrm{N}=$ the total number of informants.
Index of knowledge level (Mgj) was measured using Alexiades (1996).

$$
M g j=\frac{1}{n} \sum \quad V_{i}
$$

where

$\mathrm{Mgj}=$ the average level of knowledge of $j$ criteria

$\mathrm{n}=$ total number of $\mathrm{j}$ criteria

$\mathrm{Vi}=$ total knowledge from society $i$ in $j$ criteria

$\mathrm{j} \quad=$ age class and gender.

The level expertise on using wild swamp vegetables was analysed using Kruskal Wallis test to differentiate four classes of age. The test was carried out because the populations did not have equal variances and assumed that every group of age came from the same distribution and independent. Mann Whitney U-test was applied to determine significant differences between man and woman only to understand the level knowledge of the vegetables.

\section{RESULTS}

\section{Wild Swamp Vegetables Consumed by Banjarese}

Interviewed respondents cited six wild swamp plant species including semi-wild plants, listed in Table 1 together with local name, botanical species and family, habitus, habitat and where it is found.

\section{Plant Parts Used and Processing Techniques for Food}

Figure 2 described the percentage of used parts of plants eaten by Banjarese. 
Table 1. List of wild swamp vegetables found in Banjar regency

\begin{tabular}{|c|c|c|c|c|c|}
\hline Local name & Scientific name & Family & Habitus & $\begin{array}{l}\text { Habitat in } \\
\text { swamp }\end{array}$ & Place \\
\hline $\begin{array}{l}\text { Kangkung } \\
\text { air* }\end{array}$ & $\begin{array}{l}\text { Ipomoea } \\
\text { aquatica Forks }\end{array}$ & Convolvulaceae & Herbaceous & $\begin{array}{l}\text { Edge to the } \\
\text { middle of } \\
\text { swamp }\end{array}$ & $\begin{array}{l}\mathrm{Pj}, \mathrm{St} \& \\
\mathrm{Sb}\end{array}$ \\
\hline Genjer & $\begin{array}{l}\text { Limnocharis } \\
\text { flava }\end{array}$ & Butomaceae & Herbaceous & Edge & $\begin{array}{l}\mathrm{Pj}, \mathrm{St} \& \\
\mathrm{Sb}\end{array}$ \\
\hline Talas* & $\begin{array}{l}\text { Colocasia } \\
\text { esculenta }\end{array}$ & Araceae & Herbaceous & Edge & $\begin{array}{l}\mathrm{Pj}, \mathrm{St} \& \\
\mathrm{Sb}\end{array}$ \\
\hline Kalakai & $\begin{array}{l}\text { Stenochlaena } \\
\text { palustris Bedd. }\end{array}$ & Blechnaceae & Fern & Edge & $\mathrm{Pj}$ \\
\hline Talipuk & $\begin{array}{l}\text { Nymphaea } \\
\text { pubescens } \\
\text { Willd. }\end{array}$ & Nymphaeaceae & Herbaceous & $\begin{array}{l}\text { Edge to the } \\
\text { middle of } \\
\text { swamp }\end{array}$ & $\mathrm{Pj} \& \mathrm{Sb}$ \\
\hline $\begin{array}{l}\text { Supan- } \\
\text { supan }^{1}\end{array}$ & $\begin{array}{l}\text { Neptunia } \\
\text { oleracea Lour. }\end{array}$ & Fabaceae & Herbaceous & Edge & $\mathrm{Pj} \& \mathrm{Sb}$ \\
\hline
\end{tabular}

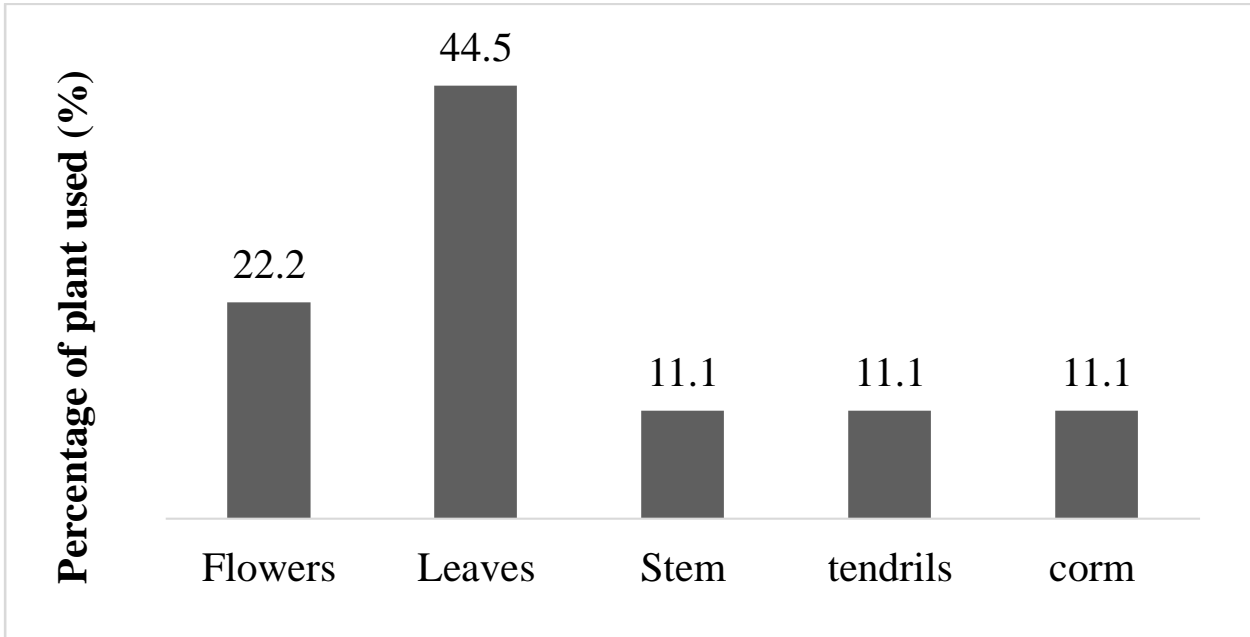

Plant parts used

Figure 2. Percent of used parts of wild swamp vegetables traditionally eaten by Banjarese.

\section{Respondents and Knowledge of Wild Swamp Vegetables}

Figure 3 described the knowledge level of respondents based on the age criteria using wild swamp vegetables. The level knowledge of wild swamp vegetables among the age classes was not significant different: $(\alpha=0.05)$ d.f
$(3.00)=5.001$ and $\mathrm{p}=0.174$ with the mean rank of $15-29 ; 30-44 ; 45-59 ; \geq 60$ years old around $30.06,32.22,40.78$ and 42.94 respectively.

Journal of Wetlands Environmental Management 
Table 2. Mode of culinary use and the ethnobotanical RFC index of wild swamp vegetables in selected three villages

\begin{tabular}{|c|c|c|c|}
\hline $\begin{array}{c}\text { Species / English } \\
\text { name }\end{array}$ & RFC & Plant parts used & Culinary use \\
\hline $\begin{array}{l}\text { Ipomoea aquatica } \\
\text { Forks / water } \\
\text { spinach }\end{array}$ & 1.00 & Leaves \& stem & $\begin{array}{l}\text { a. Gangan asam } \\
\text { Heated } 2 \text { spoons oil \& added blend seasons (candlenut, red onion, garlic, turmeric, } \\
\text { shrimp paste, greater galangal, lemon grass), stirred until fragrant about } 1 \text { minute. } \\
\text { Then, added to the boiled water with water spinach, green beans, catfish, cucumber, } \\
\text { tomatoes, red pepper and bilimbi. } \\
\text { b. Gangan tungkul } \\
\text { Boiled water and added water spinach, young flowers of bananas and seasons (red } \\
\text { onion, garlic, lemon grass, turmeric, greater galangal, candlenut, tamarind) and } \\
\text { snakehead fish. Lastly, added coconut milk and brought to a boil. } \\
\text { c. Gangan keladi } \\
\text { Boiled } 2 \text { lt water and added blend spices (red onion \& garlic), tamarind, taro corm, } \\
\text { water spinach and flowers of hairy water lily. } \\
\text { d. Ubar haruan } \\
\text { Boiled water spinach } 5 \text { minutes and then put it in sambal/chili sauce. Added the fried } \\
\text { snakehead fish and put it water lemon to make tastier. } \\
\text { e. Tumis kangkung } \\
\text { Heated } 2 \text { spoons oil and added the chop red onion \& garlic and added water spinach. }\end{array}$ \\
\hline $\begin{array}{l}\text { Limnocharis flava / } \\
\text { genjer }\end{array}$ & 0.96 & $\begin{array}{l}\text { Young leaves\& } \\
\text { buds }\end{array}$ & $\begin{array}{l}\text { a. Urap genjer } \\
\text { Boiled genjer } 3 \text { minutes and then put it in fried mix spices (aromatic ginger, red chilli, } \\
\text { shrimp paste, lime leaves\& grated coconut) } \\
\text { b. Tumis genjer } \\
\text { Chopped genjer and washed with boiled water. Fried a blend of spices (red onion, } \\
\text { garlic \& red chili) and put the vegetables and stirred until fragrant. }\end{array}$ \\
\hline
\end{tabular}


Table 2 (Continued)

\begin{tabular}{|c|c|c|c|}
\hline $\begin{array}{l}\text { Colocasia esculenta } \\
\text { / taro }\end{array}$ & 0.71 & Corm\& tendril & $\begin{array}{l}\text { a. Gangan keladi } \\
\text { Chopped tendril \& corm and then boiled. Fried a blend of spices (red onion, garlic, } \\
\text { candlenut, turmeric\& red pepper) mixted with greater galangal and lemon grass. } \\
\text { Lastly, put the snakehead fish and the chopped vegetables. } \\
\text { b. Gangan pisang - keladi } \\
\text { Chopped tendril, corm \& young banana and then boiled with tamarind and then drain. } \\
\text { Boiled water with coconut milk and a blend of spices (turmeric, candlenut, lemon } \\
\text { grass, shrimp paste) and lastly added the vegetables. }\end{array}$ \\
\hline $\begin{array}{l}\text { Neptuniaoleracea } \\
\text { Lour. / water } \\
\text { mimosa }\end{array}$ & 0.57 & Young leaves & $\begin{array}{l}\text { a. Gangan karuh } \\
\text { Fried a blend of seasons (shrimp paste, turmeric, garlic, red onion \& candlenut) until } \\
\text { fragrant. Added Supan-supan together with snakehead fish and boiled. } \\
\text { b. Tumis supan-supan } \\
\text { Fried a blend of spices (red onion, garlic, red chili) until fragrant and put Supan-supan } \\
\text { and stirred it }\end{array}$ \\
\hline $\begin{array}{l}\text { Stenochlaena } \\
\text { palustris Bedd. / } \\
\text { swamp fern }\end{array}$ & 0.56 & Young leaves & $\begin{array}{l}\text { a. Tumis kalakai } \\
\text { Fried red onion and garlic until fragrant and then added the chopped kalakai. } \\
\text { b. Kalakai besantan } \\
\text { Fried a blend of seasons (red onion, garlic, red chili, ginger and turmeric) until } \\
\text { fragrant and then added coconut milk, tofu and chopped kalakai. }\end{array}$ \\
\hline $\begin{array}{l}\text { Nymphaea } \\
\text { pubescens Willd. / } \\
\text { hairy water lily }\end{array}$ & 0.47 & Petiole, flowers & $\begin{array}{l}\text { a. Tumis talipuk } \\
\text { Fried the chopped red onion and garlic until fragrant and then put red pepper and } \\
\text { tomato. Lastly, added petiole and flower. } \\
\text { b. Gangan keladi-talipuk } \\
\text { Boiled water with a blend of seasons (red onion and garlic) together with tamarind. } \\
\text { Added flowers of talipuk and water spinach. }\end{array}$ \\
\hline
\end{tabular}

RFC $=$ Relative Frequency of Citation Index 


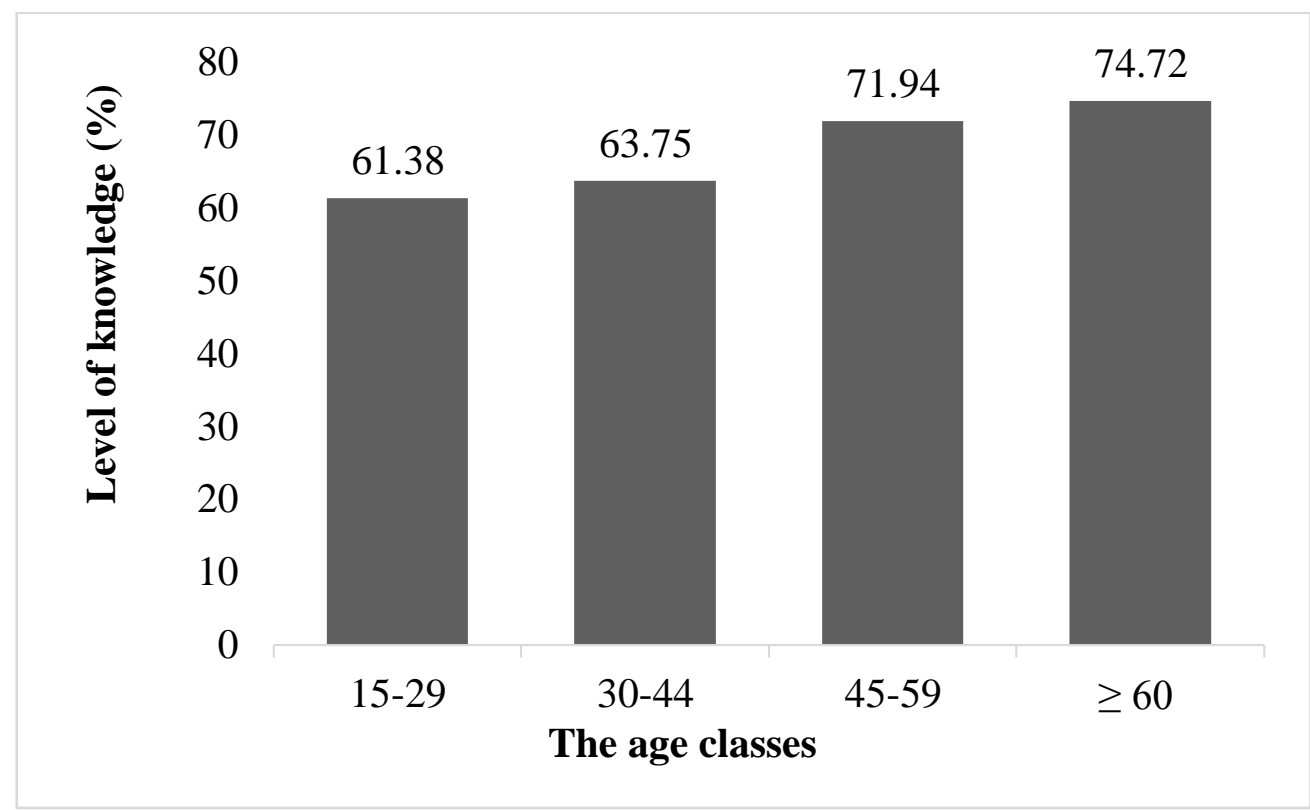

Figure 3. The percentage of level knowledge of wild swamp vegetables among the age classes at three villages

\section{DISCUSSION}

\section{Wild Swamp Vegetables Consumed by Banjarese}

Based on Table 1, six wild swamp plants were commonly found in Pajambuan village rather than in other villages because the area of swamp was suitable for those plants lives in. The perfect habitat of all wild swamp vegetables requires clay soils which rich in nutrient contents, high soil moistures and soil $\mathrm{pH}$ range from slightly acid to normal. In addition, the term "wild" is generally associated with unmanaged environments (Chauhan et al., 2018).

Genjer, Talas, Kalakai and Supan-supan were relatively found at the edge of the swamp, while Kangkung air and Talipuk were easily found from the outer to the centre of swamp.
Most of recorded plants except Kalakai and Supan-supan are commonly consumed at South Kalimantan province, while others were used at particular areas, both for additional vegetables and medicine. Kalakai as an edible swamp fern was used by Banjarese to treat anemia (Chai et al., 2012) while Supan-supan or water mimosa was consumed for food and had the advantages as aphrodisiac. Thai cuisine often uses Supansupan for a spicy and sour salad combined with sea foods (Csurhes, 2016) and two countries such as Malaysia and Nigeria utilize it to heal yellow fever and syphilis (Ita, 1994; Paisooksantivatana, 1993).

\section{Plant Parts Used and Processing Techniques for Food}

Leaves were the common plant parts utilized as vegetables compared to other plant sections by $44.5 \%$ followed by flowers with $22.2 \%$. 
Stem, tendrils and corms cite as an equal percentage of plant utilized of $11.1 \%$ (Fig 2). Supriati et al. (2012) declared that for vegetables the leaves referred to as leafy vegetables were mainly eaten. Leaves were easily harvested and cooked. They were called greens, salad greens, potherbs or leafy greens and sometimes shared with other plant parts in cooking methods. Moreover, leafy vegetables form an important portion of Banjarese diet and become dietary constituent.

Table 2 described that the Banjar generally used water spinach based on RFC index of 1.00 as an alternative food combined with rice. It means that water spinach plays a vital role as food for Banjarese. The use of water spinach was previously reported in another study (Suratman et al., 2000). All informants cooked water spinach because the availability of the plant all over the season. Moreover, it grows easily without any particular treatment from the outer to the centre of the swamp. Water spinach became more popular within local community because of easy to cook. The local recipes of the Banjar were gangan asam, gangan tungkul, gangan keladi, ubar haruan and tumis kangkung which sometime mixed with other vegetables, coconut milk and local swamp fishes such as snakehead fish and catfish. The culinary delights of Banjarese was a heredity recipe which had nutritious values based on Departemen Kesehatan Republik Indonesia (1981). Most informants knew the benefits of water spinach for human health; however, no one understood preparation techniques for medicine.

The second vegetable consumed by Banjarese was genjer which had 0.96 of RFC index. Plant parts used like young leaves, petioles, and buds were cooked such urap genjer and tumis genjer. Sometimes people combined genjer with water spinach to make urap. Juhaeti (2013) stated that genjer grew wildly at paddy field; however, based on the observation genjer could be found at the edge of swamps. Young leaves of genjer contain high vitamin, fat, zinc, calcium and phosphor (Juhaeti, 2013).

Taro usually was boiled first before consumed to reduce needle-like crystals (oxalic acid) that cause unpleasant itching (Koswara, 2010). Preparation technique of Banjarese's recipes to cook taro used boiled water and tamarinds then drain it. Then, it can be made some recipes like gangan keladi and gangan pisang-keladi. Sometimes Banjarese made chips from taro's corm. Local people in three villages consumed taro with RFC index of 0.71. It meant taro was local important vegetables under water spinach and genjer.

Water mimosa was consumed solely the young leaves such gangan karuh and tumis supan-supan, while in Thailand it is cooked as salad (raw young leaves) based on Csurhes (2016). Banjarese utilized water mimosa as tumis and additional vegetables in another recipe and the vegetables had local importance around 0.57 of RFC index.

Swamp fern and hairy water lily had a RFC index of 0.56 and 0.47 respectively. Swamp fern was consumed only the young leaves and some respondents knew the benefits of it to boost breast milk and to heal irritating. Maharani et al. (2006) stated that swamp fern had a high calcium of $182.07 \mathrm{~g}$ and iron of $291.32 \mathrm{~g}$ of 100 $\mathrm{g}$ dry mass that potential to prevent anemia.

Petiole and flowers of hairy water lily were consumed by local people; however, in other areas Banjarese used the fruits to make a traditional snack called talipuk. The fruits firstly processed into flour for the base material of cake. According to Fitrial (2009) the fruit contained essential nutrients namely protein, fat and carbohydrat of $8.13 \mathrm{~g}, 0.51 \mathrm{~g}$ and $78.76 \mathrm{~g}$ of 
$100 \mathrm{~g}$ fruit respectively. Therefore, the fruit potency can be as an alternative staple food for local societies and based on Departemen Kesehatan (1997) its potency can heal dysentery and diarrhoea. Although hairy water lily had a great advantage of human's welfare; however, Banjarese at three selected villages solely used it 0.47 of a RFC index because the plant growth slowly compared to others.

\section{Respondents and knowledge of wild swamp vegetables}

Seventy-two informants attached to indigenous knowledge on using six wild swamp plants for food. Commonly, women were more have time to speak about wild swamp vegetables due to most their daily activities are at home. According to Mann Whitney U test, the women $($ mean $=48.98)$ resulted more wild swamp vegetables than the men $($ mean $=24.03)$ did and the level knowledge of using wild swamp plants for food based on the gender was significantly different (Mann Whitney U-test statisctics ${ }_{(\alpha=0.05)}(\mathrm{Z}=-5.084) \quad=200,000$ and $\mathrm{p}=0.000$ ). Although both females and men had the same occupation as a rice farmer, the women learned from their parents through routine observations on utilizing wild swamp vegetables and processing them into local recipes combined with rice as the staple food. Moreover, the females had more time in their home to nurture their children or families. Consequently, the collecting, processing and cooking of wild swamp vegetables were almost exclusively done by the females. Other studies conducted in some places (Sansanelli et al., 2017; Pieroni et al., 2002) also resulted in the same trend that women have more knowledge on utilizing wild swamp vegetables.

Index of knowledge level among the age classes showed different result according to Figure 3. All age classes had knowledge on using wild swamp plants more than $60 \%$ and the highest percent was noted for the elder people counted of $74.72 \%$. The picture shows the gradually increase of knowledge level among the age criteria from $61.38 \%$ of young generation to $74.72 \%$ of the elderly. However, based on the Kruskal Wallis test the level knowledge of wild swamp vegetables among the age classes was not significant different. The knowledge on using wild swamp vegetables preserves constantly between the young generation and the old one, because, the knowledgeable person transferred properly to the next descendants. Moreover, the younger one had the opportunity learning the indigenous knowledge directly in the field.

\section{CONCLUSSION}

The study has revealed that Banjarese who are living in Pajambuan, Sungai Tuan Ilir and Sungai Batang villages of Banjar regency, South Kalimantan province, utilize wild swamp vegetables as an alternative meal and their level knowledge among all age generations achieve equal positions.

\section{ACKNOWLEGEMENT}

We are grateful to all respondents who shared their knowledge on utilizing wild lowland swamp plants for food and thankful to the local government for assisting us in the field.

\section{REFERENCES}

Alexiades, M.N. (1996). Selected guidelines for ethnobotanical research: A field manual. Advances in economic botany, vol.10. The New York Botanical Garden. Bronx.

Arowosegbe, S., Olanipekun, M. K. \& Adeloye, I. A. (2018). Ethnobotanical survey of 
indigenous leafy vegetables consumed in Ekiti State, Nigeria. European Journal of Biology and Medical Science Research, 6 (1), 7-14.

Chai, T.T., Panirchellvum, E., Ong, H. C. \& Wong F.C. (2012). Phenolic contents and antioxidant properties of Stenochlaena palustris, an edible medicinal fern. Botanical Studies, 53, 439-446.

Chauhan, S. H., Yadav, S., Takahashi, T., Luczaj, L., D’Cruz, L. \& Okada, K. (2018). Consumption patterns of wild edibles by the Vasavas: a case study from Gujarat, India. Journal of Ethnobiology and Ethnomedicine, 14 (57): 1-20.

Cotton, C.M. (1996). Ethnobotany: Principles and application. John Wiley \& Sons. New York.

Csurhes, S. (2016). Water mimosa Neptunia oleracea, Dead and Wake Neptunia plena. Invasive plant risk assessment. State of Queenslaand. Australia.

Departemen Kesehatan Republik Indonesia. (1981). Daftar komposisi bahan makanan. Bhratara. Jakarta.

Departemen Kesehatan Republik Indonesia. (1997). Daftar komposisi bahan makanan. Bhratara. Jakarta.

Fitrial, Y. (2009). Analisis potensi biji dan umbi teratai Nymphaea pubescens Willd untuk pangan antibiotic dan antibakteri Escherichia coli enteropatogenik K1.1. Thesis. IPB. Bogor.

Ita, E.O. (1994). Aquatic plants and wetland wildlife resources of Nigeria. FAO. Rome.

Juhaeti, T. (2013). Respon genjer Limnocharis flava (L.). Buchenau. Terhadap pemupukan dan potensi gizinya untuk diversifikasi konsumsi sayuran. Jurnal Berita Biologi, 12 (1), 107-116.

Koswara. (2010). Bagian I: Pengolahan umbi talas. Modul Teknik pengolahan umbiumbian. IPB. Bogor.

Leonti, M., Nebel, S., Rivera, D. \& Heinrich, M. (2006). Wild gathered food plants in the European Mediterranean: A comparative analysis. Economic Botany, 60, 130-142.
Local Government of Banjar Regency. (2006). Kondisi Kabupaten Banjar Kalimantan Selatan. Banjarmasin.

Lyatuu, E. \& Lebotse, L. (2010). Marketing of indigenous leafy vegetables and how smallscale farmers can improve their incomes. (eds). Agricultural Research Council. Tanzania.

Maharani, M. (2006). Studi potensi kalakai Stenoclaena palustris sebagai pangan fungsional. Universitas Lambung Mangkurat. Banjarbaru.

Maritim, A.C., Sanders, R. A., \& Watkins, J. B. (2003). Diabetes, oxidative stress, and antioxidant: A review. Journal Biochemistry Molecular Toxic, 17, 24-38.

Martin, J. F., Roy, E.D., Diemont, S. A. W. \& Ferguson, B. G. (2010). Traditional ecological knowledge (TEK): Ideas, inspiration, and design for ecological engineering. Ecological Engineering, 36, 839-849.

Millennium Ecosystem Assessment. (2005). Ecosystems and human well-being: Wetlands and water. Synthesis. World Resources Institute. Washington.

Page, S., Rieley, J.O. \& Banks, C. J. (2011). Global and regional importance of the tropical peatland carbon pool. Global Change Biology, 17, 798-818.

Paisooksantivatana, Y. (1993). Neptunia oleracea Loureiro, Plant Resources of SouthEast Asia no. 8: Vegetables. (eds). Wageningen. Netherlands.

Pieroni, A., Nebel, S., Quave, C., Munz, H. \& Heinrich, M. (2002). Ethnopharmacology of liakra: Traditional weedy vegetables of the Arbereshe of the vulture area in southern Italy. Journal Ethnopharmacology, 81, 165185. (in Indonesian)

Pitoyo, A. J. \& Triwahyudi, H. (2017). Dinamika perkembangan etnis di Indonesia dalam konteks persatuan negara. Populasi, 25 (1), 64-81.

Purwanto, Y. (1999). Peran dan peluang etnobotani masa kini di Indonesia dalam menunjang upayak onservasi dan pengembangan keanekaragaman hayati. 
Prosiding Seminar Hasil Penelitian Bidang Ilmu Hayati. IPB. Bogor.

Raihani. (2018). Banjarese Islamic scholars ('ulema) and social transformation in Tembilahan (preliminary research). Journal Ushuluddin, 26 (2), 215-224.

Ray, A.J. (2015). Traditional knowledge and social science on trial: Battles over evidence in indigenous rights litigation in Canada and Australia. The International Indigenous Policy Journal, 6 (2).

Romojaro, A., Botella, M.A., Obon, C. \&Pretel, M. (2013). Nutritional and antioxidant properties of wild edible plants and their use as potential ingredients in the modern diet. International Journal Food Science Nutrition, 64, 944-952.

Sansanelli, S., Ferri, M., Salinitro, M. \& Tassoni, A. (2017). Ethnobotanical survey of wild food plants traditionally collected and consumed in the Middle Agri Valley (Basilacata region, southern Italy). Journal of Ethnobiology and Ethnomedicine, 13, 1-10.

Shei, L. (2008). An evaluation of native West African vegetables. Agricultural and Rural Development. www.tropentag.de (Accessed in September 2018).

Supriati, R., Nurliana, S. \& Malau, F. (2012). Keanekaragaman jenis tumbuhan yang dimanfaatkan oleh masyarakat Desa Tanah Hitam Kecamatan Padang Jaya Kabupaten Bengkulu Utara. Jurnal Konservasi Hayati, 8 (1), 44-50.
Suratman, D., Priyanto \& Setyawan, D. (2000). Analisis keragaman genus Ipomoea berdasarkan karakter morfologi. Jurnal Biodiversitas, 1 (2), 72-79.

Suryadarma, I. G. P. (2008). Diktat kuliah etnobotani. Pendidikan Biologi. UNY. Yogyakarta.

Susanti, H. (2015). Studi etnobotani sayuran local khas rawa di pasar Martapura Kalimantan Selatan. Jurnal Ziraa'ah, 40 (2), 140-144.

Stuip, M. A. M., Baker, C. J. \&Oosterberg, W. (2002). The socio-economics of wetlands. Wetland international and RIZA. The Netherlands.

Tardio, J. \& Pardo-de-Santaya. (2008). Cultural importance indices: A comparative analysis based on the useful wild plants of southern Cantabria (northern Spain). Economic Botany, 62, 24-39.

Teklehaymanot, T. (2009). Ethnobotanical study of knowledge and medicinal plants use by the people in Dek island in Ethiopia. Journal of Ethnopharmacology, 124, 69-78.

Wetlands International. (2010). Wetlands and water, sanitation and Hygiene (WASH): Understanding the linkage. The Netherlands.

Xu, J., Ma, E. T., Tashi, D., Fu, Y., Lu, Z. \&Melick, D. (2005). Integrating sacred knowledge for conservation: Cultures and landscapes in southwest China. Ecology and Society, 10 (2), 7. 